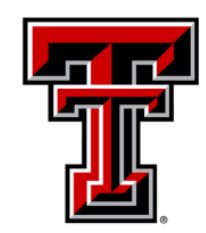

TEXAS TECH UNIVERSITY

Libraries"

\title{
EFFECTS OF RACTOPAMINE AND GENDER ON PROTEIN TURNOVER IN SKELETAL MUSCLE OF IMPLANTED STEERS AND HEIFERS
}

\section{The Texas Tech community has made this publication openly available. Please share how this access benefits you. Your story matters to us.}

\begin{tabular}{|l|l|}
\hline Citation & $\begin{array}{l}\text { Walker, D. K., Titgemeyer, E. C., Johnson, D. E., Laudert, S. B., } \\
\text { \&amp; Johnson, B. J. (2011). Effects of ractopamine and gender on } \\
\text { protein turnover in skeletal muscle of implanted steers and heifers. } \\
\text { South African Journal of Animal Science, 41(1). } \\
\text { https://doi.org/10.4314/sajas.v41i1.66033 }\end{array}$ \\
\hline Citable Link & $\underline{\text { https://hdl.handle.net/2346/87799 }}$ \\
\hline Terms of Use & $\underline{\text { CC BY 2.5 ZA }}$ \\
\hline
\end{tabular}




\title{
Effects of ractopamine and gender on protein turnover in skeletal muscle of implanted steers and heifers
}

\author{
D.K. Walker ${ }^{1}$, E.C. Titgemeyer ${ }^{1 \#}$, D.E. Johnson ${ }^{2}$, S.B. Laudert ${ }^{3}$, B.J. Johnson ${ }^{1}$ \\ ${ }^{1}$ Department of Animal Sciences and Industry, Kansas State University, Manhattan, KS, USA \\ ${ }^{2}$ Department of Statistics, Kansas State University, Manhattan, KS, USA \\ ${ }^{3}$ Elanco Animal Health, Greenfield, IN, USA
}

Copyright resides with the authors in terms of the Creative Commons Attribution 2.5 South African Licence.

See: http://creativecommons.org/licenses/by/2.5/za/

Condition of use: The user may copy, distribute, transmit and adapt the work, but must recognise the authors and the South

African Journal of Animal Science

\begin{abstract}
Effects of the $\beta$-agonist, ractopamine- $\mathrm{HCl}$ (ractopamine), on skeletal muscle protein turnover were evaluated in 16 steers $(512 \mathrm{~kg})$ and 16 heifers $(473 \mathrm{~kg})$. Treatments were arranged in a $2 \times 2$ factorial design and included gender (steer $v s$. heifer) and ractopamine $(0$ or $200 \mathrm{mg} / \mathrm{d})$. Steers were implanted with $120 \mathrm{mg}$ trenbolone acetate and $24 \mathrm{mg}$ estradiol- $17 \beta$, heifers with $140 \mathrm{mg}$ trenbolone acetate and $14 \mathrm{mg}$ estradiol-17 . Cattle were fed a diet based on steam-flaked maize. Muscle biopsy samples were collected from $m$. longissimus and $m$. biceps femoris on day 0 (prior to ractopamine feeding) and after 14 and $28 \mathrm{~d}$ of ractopamine feeding. In vitro protein synthesis rates in $m$. longissimus tended to be greater for steers than for heifers, but no effect of gender was observed in $m$. biceps femoris. Gender did not affect in vitro protein degradation rates for either muscle. Ractopamine significantly decreased rates of in vitro protein degradation in $m$. longissimus, but rates in $m$. biceps femoris were not affected by ractopamine. Ractopamine did not affect in vitro protein synthesis rates. In general, there were no striking differences between steers and heifers in response to ractopamine, indicating that its effectiveness should be similar between genders.
\end{abstract}

Keywords: Cattle, $\beta$-agonist, protein turnover, ractopamine

${ }^{\#}$ Corresponding author: etitgeme@ksu.edu

\section{Introduction}

Ractopamine- $\mathrm{HCl}$ (ractopamine) is a $\beta$-adrenergic agonist with primary affinity for $\beta_{1}$-adrenergic receptors and lesser affinity for $\beta_{2}$-adrenergic receptors (Moody et al., 2000). When fed to cattle, ractopamine results in an increase in muscle mass (Mersmann, 1998).

Ractopamine improves growth rate and feed efficiency in both steers and heifers, but responses in heifers have been less than in steers, suggesting there may be some difference between genders in how ractopamine affects growth. Feeding $200 \mathrm{mg} / \mathrm{d}$ of ractopamine for $28 \mathrm{~d}$ increased hot carcass weights in steers (implanted with $120 \mathrm{mg}$ trenbolone acetate and $24 \mathrm{mg}$ estradiol) by $5.5 \mathrm{~kg}$ (Gruber et al., 2007) and 8 $\mathrm{kg}$ (Winterholler et al., 2007), whereas improvements in hot carcass weights were $1 \mathrm{~kg}$ in implanted (140 mg trenbolone acetate and $14 \mathrm{mg}$ estradiol) heifers and $4 \mathrm{~kg}$ in non-implanted heifers (Quinn et al., 2008) and 2.3 and $5 \mathrm{~kg}$ in heifers receiving final implants containing $200 \mathrm{mg}$ trenbolone acetate (Sissom et al., 2007).

There is evidence that $\beta$-agonists increase protein deposition, at least in part, by decreasing protein degradation rates. Urinary excretion of $\mathrm{N}$-methylhistidine by cattle was reduced by treatment with the $\beta$-agonist $\mathrm{L}_{644,969}$ (Wheeler \& Koohmaraie, 1992). Similarly, calpastatin is increased by the $\beta$-agonist $\mathrm{L}_{644,969}$, which also supports the idea that muscle protein degradation is reduced by $\beta$-agonists (Wheeler \& Koohmaraie, 1992). In contrast, techniques that calculate protein degradation as the difference between protein synthesis and protein accretion have at times led to the conclusion that protein degradation may be increased by $\beta$-agonists (Bergen et al., 1989; Nash et al., 1994).

The increase in shear force of $m$. longissimus from cattle fed $\beta$-agonists suggests that muscle protein degradation is inhibited by $\beta$-agonists. However, zilpaterol leads to a greater impact on shear force than does ractopamine (Avendano-Reyes et al., 2006), so it might be unwise to extrapolate among $\beta$-agonists. Most 
research on the impact of $\beta$-agonists on meat quality has been conducted with the $m$. longissimus, but differences in responsiveness to ractopamine exist among muscles (Gonzalez et al., 2009).

Our objective was to determine the effects of feeding ractopamine to finishing steers and heifers at 200 $\mathrm{mg} / \mathrm{d}$ for 14 or $28 \mathrm{~d}$ on skeletal muscle protein turnover.

\section{Materials and Methods}

Procedures for this study were approved by the Kansas State University Institutional Animal Care and Use Committee (protocol \#2508).

Thirty-two Angus cattle were used. The experiment used a randomised complete block design with treatments being gender (steer or heifer, 16 of each) and ractopamine $(0$ or $200 \mathrm{mg} / \mathrm{d}$; Optaflexx; Elanco Animal Health, Greenfield, IN, USA). At 90 to $97 \mathrm{~d}$ before the experiment, steers were implanted with 120 mg trenbolone acetate and $24 \mathrm{mg}$ estradiol (Component TE-S, Vet Life, West Des Moines, IA, USA), and heifers were implanted with $140 \mathrm{mg}$ trenbolone acetate and $14 \mathrm{mg}$ estradiol (Component TE-H, Vet Life). Management and performance of the cattle has been described (Walker et al., 2010).

Eight blocks containing two steers and two heifers were generated according to body weight and pretrial average daily gain, and cattle were randomly assigned to ractopamine treatment within gender and block. Cattle were fed and housed individually in $4.5 \times 1.5 \mathrm{~m}$ pens and given ad libitum access to water and feed (75\% steam-flaked maize, $10 \%$ lucerne hay; diet contained $145 \mathrm{~g}$ crude protein $/ \mathrm{kg}$; Walker et al., 2010). Fresh feed was provided once daily.

The start of the experiment was staggered over time to ensure samples could be handled in a timely fashion. Two blocks of cattle were started concurrently, with subsequent groups of two blocks starting 1, 7, and $8 \mathrm{~d}$ later. Biopsy samples were collected before ractopamine feeding (day 0) and after 14 and $28 \mathrm{~d}$ of ractopamine feeding. On each day of sample collection, muscle biopsy samples were collected from the $m$. biceps femoris and $m$. longissimus beginning at 06:30. For two blocks, cattle assigned to the ractopamine treatment mistakenly received ractopamine on the day before the initial sampling; data from these day- 0 samples were not used for statistical analysis, and samples collected after 15 and $29 \mathrm{~d}$ of ractopamine feeding were considered equivalent to those collected after 14 and $28 \mathrm{~d}$ of ractopamine feeding.

Biopsy samples were collected from the $m$. biceps femoris and $m$. longissimus using a 6-mm Bergstrom biopsy needle (Dunn et al., 2003; Pampusch et al., 2003) with lidocaine as a local anaesthetic; each insertion of the biopsy needle yielded approximately $2 \mathrm{~g}$ of tissue. Biopsies on day 0 and 28 were collected from the left side, and biopsies on day 14 were collected from the right side. The $m$. longissimus sampling sites initially were at the last rib and moved $5 \mathrm{~cm}$ anterior for the final sampling. The $m$. biceps femoris sampling sites initially were midway between the trochanter major of the femur and the tuber ischii and moved $5 \mathrm{~cm}$ ventral for the final sampling.

In vitro protein synthesis rates in biopsy samples were determined as described by Greig et al. (1986). Samples (150 to $300 \mathrm{mg}$ ) were blotted on sterile gauze and placed in pre-incubation medium for transport to the laboratory. The pre-incubation medium contained Krebs-Ringer bicarbonate buffer, saturated with $95 \% \mathrm{O}_{2}: 5 \% \mathrm{CO}_{2}$ by bubbling for $30 \mathrm{~min}, 10 \mathrm{~m} M$ glucose, $0.1 \mathrm{IU}$ porcine insulin/mL, and 20 amino acids (mM; Ala 4.5, Arg 2.0, Asn 0.7, Asp 0.35, Cys 0.7, Glu 2.0, Gln 3.5, Gly 4.0, His 0.8, Ile 1.0, Leu 1.7, Lys 4.0, Met 0.7, Phe 0.8, Pro 1.8, Ser 2.8, Thr 3.0, Trp 0.7, Tyr 0.7, and Val 2.0). For each muscle from each animal, 20 to $40 \mathrm{mg}$ of tissue was placed into each of five incubation tubes containing $3.0 \mathrm{~mL}$ of incubation medium, regassed with $95 \% \mathrm{O}_{2}: 5 \% \mathrm{CO}_{2}$, and incubated for $3 \mathrm{~h}$ at $37{ }^{\circ} \mathrm{C}$ in a metabolic shaker bath. The incubation medium contained the pre-incubation media plus $1.8 \mu \mathrm{Ci} \mathrm{L}-\left[{ }^{3} \mathrm{H}\right]$-tyrosine. After incubation, tissue samples were removed from the media, blotted, weighed, frozen in liquid $\mathrm{N}_{2}$, and stored at $-20{ }^{\circ} \mathrm{C}$. The medium was frozen in liquid $\mathrm{N}_{2}$ and stored at $-20{ }^{\circ} \mathrm{C}$.

Muscle samples were homogenised (Tissue Tearor; Biospec Products, Inc., Bartlesville, OK, USA) in $2.5 \mathrm{~mL}$ of $10 \mathrm{~m} M$ potassium phosphate buffer ( $\mathrm{pH} 7.4$ at 0 to $5^{\circ} \mathrm{C}$ ). Protein was precipitated from $2.0 \mathrm{~mL}$ of homogenate with $1 \mathrm{~mL}$ of $30 \%$ (wt/vol) trichloroacetic acid at 0 to $5{ }^{\circ} \mathrm{C}$ and centrifuged at $11000 \times g$ for 10 min. The protein pellet was washed twice with $10 \%(\mathrm{wt} / \mathrm{vol})$ trichloroacetic acid and dissolved in $1.0 \mathrm{~mL}$ of tissue solubiliser (NCS-II Tissue Solubilizer, Amersham Biosciences, Little Chalfont Buckinghamshire, England) at $65{ }^{\circ} \mathrm{C}$ for $30 \mathrm{~min}$. The solution was poured into a scintillation vial with $15 \mathrm{~mL}$ of scintillation cocktail (ScintiSafe Plus 50\%, Fisher Scientific, Hanover Park, IL, USA). Samples were allowed to stand overnight in low lighting to reduce chemiluminescence before being counted in a scintillation counter.

The medium $\left(3.0 \mathrm{~mL}\right.$ ) was acidified with $1.0 \mathrm{~mL}$ of $40 \%$ (wt/vol) trichloroacetic acid at 0 to $5{ }^{\circ} \mathrm{C}$ and 
centrifuged at $11000 \times g$ for $10 \mathrm{~min}$. An aliquot of the supernatant was analysed for tyrosine concentration as described by Waalkes \& Udenfriend (1957), and a 1.0-mL aliquot was counted for radioactivity.

Protein synthesis rates were estimated by ${ }^{3} \mathrm{H}-\mathrm{Tyr}$ incorporation into protein. The equation used to calculate synthesis rates was: protein synthesis rate $=[\mathrm{dpm}$ in protein / specific activity of free Tyr, $\mathrm{dpm} / \mu \mathrm{g}]$ /(wet tissue weight, $\mathrm{g} \times 3 \mathrm{~h}$ ). Concentration of $\operatorname{Tyr}(0.7 \mathrm{mM})$ was 10 times that of bovine plasma; therefore, Tyr was assumed to equilibrate between the medium and intracellular precursor pool. Consequently, specific activity of Tyr in the medium was used as the specific activity of the precursor pool.

In vitro protein degradation rates in biopsy samples were determined as described by Greig et al. (1986). Samples (150 to $300 \mathrm{mg}$ ) were blotted on sterile gauze and placed in pre-incubation medium for transport to the laboratory. The pre-incubation medium contained Krebs-Ringer bicarbonate buffer with 10 $\mathrm{m} M$ glucose. For each muscle from each animal, 20 to $40 \mathrm{mg}$ of tissue was placed into each of six incubation tubes containing $3.0 \mathrm{~mL}$ of incubation medium (pre-incubation media and $0.5 \mathrm{~m} M$ cycloheximide) and regassed with $95 \% \mathrm{O}_{2}: 5 \% \mathrm{CO}_{2}$. Three incubation tubes were immediately frozen in liquid $\mathrm{N}_{2}$ and used to measure background concentrations of free Tyr. Three tubes were incubated for $3 \mathrm{~h}$ at $37{ }^{\circ} \mathrm{C}$ in a metabolic shaker bath. After incubation, samples were frozen in the medium in liquid $\mathrm{N}_{2}$ and stored at $-20^{\circ} \mathrm{C}$.

Muscle samples were homogenised in medium. An aliquot of the homogenate was assayed for protein concentration via a Coomassie Blue Protein Assay Kit (Pierce, Rockford, IL, USA). Protein was precipitated from $1.0 \mathrm{~mL}$ of homogenate with $0.5 \mathrm{~mL}$ of $30 \%$ (wt/vol) trichloroacetic acid at 0 to $5{ }^{\circ} \mathrm{C}$ and centrifuged at $11,000 \times g$ for $10 \mathrm{~min}$. A $1.0-\mathrm{mL}$ aliquot of the supernatant was analyzed for Tyr concentration (Waalkes \& Udenfriend, 1957).

Protein degradation rates were estimated by Tyr release. Cycloheximide was included in the incubation media to inhibit protein synthesis, thereby preventing reutilization of released Tyr. The equation used to calculate degradation rates was: protein degradation rate $=[($ Tyr in incubated samples $/ \mathrm{mg}$ protein $)-$ (Tyr in un-incubated samples/mg protein)] $/ 3 \mathrm{~h}$, where $3 \mathrm{~h}$ is the incubation time.

Concentrations of DNA, RNA, and protein were determined in $m$. longissimus and m. biceps femoris biopsy samples collected on day 28. Approximately $300 \mathrm{mg}$ of tissue was ground into powder with a mortar and pestle submerged in liquid $\mathrm{N}_{2}$. One hundred milligrams of ground sample, in duplicate, was used to isolate total RNA from m. biceps femoris and $m$. longissimus samples as described by Dunn et al. (2003) and Pampusch et al. (2003). Concentration of RNA was determined by absorbance at $260 \mathrm{~nm}$.

Twenty five milligrams of ground sample, in duplicate, was used to isolate DNA via a DNeasy Blood and Tissue Kit (Qiagen, Valencia, CA, USA; Blin \& Stafford 1976). To determine DNA concentration, 100 $\mu \mathrm{L}$ of sample was mixed with phosphate buffer containing bisbenzimidazole (compound $\mathrm{H}$ 33258) to a final concentration of $1 \mu \mathrm{g} / \mathrm{mL}$ as described by Labarca \& Paigen (1980). Fluorescence was measured with a fluorimeter (HP 1046A Programmable Fluorescence Detector; Santa Clara, CA, USA; excitation, 356 nm; emission, $458 \mathrm{~nm}$ ) within $16 \mathrm{~h}$ of mixing. Concentration of DNA was determined by comparison to an external standard curve of bovine calf thymus DNA in a range to $5.0 \mu \mathrm{g} / \mathrm{mL}$. Analysis of muscle composition for the $m$. longissimus sample from one heifer fed ractopamine yielded unreasonable data, so observations for this sample were excluded from statistical analysis.

Ten milligrams of ground sample was placed into $500 \mu \mathrm{L}$ of phosphate buffer $\left(0.05 \mathrm{MNa}_{2} \mathrm{HPO}_{4}, 2 \mathrm{M}\right.$ $\mathrm{NaCl}$, adjusted to $\mathrm{pH}$ 7.4) and homogenised. Protein concentration was determined from an aliquot of the homogenate with the Coomassie Blue Protein Assay Kit (Pierce).

Data were analysed using the MIXED procedure of SAS System for Windows Release 9.1 (SAS Inst. Inc., Cary, NC, USA). Data for RNA, DNA, and protein concentrations were analysed as a randomised complete block design with a model containing gender, ractopamine, and ractopamine $\times$ gender; block was a random effect. Protein turnover data were analysed as a randomised complete block design with repeated measures, and day- 0 values were used as covariates. The model included the covariate, gender, ractopamine, ractopamine $\times$ gender, day, ractopamine $\times$ day, gender $\times$ day, and ractopamine $\times$ gender $\times$ day; block was a random effect. Day was the repeated variable, and animal was the experimental unit; the covariance structure was unstructured. Values were predicted for missing values from day 0 with the same model, but without the inclusion of the covariate. Use of covariates removed much of the gender effect, so data were analysed for the main effect of gender using the model described above without covariates. 


\section{Results}

Effects of gender on in vitro protein synthesis and degradation rates are presented in Table 1. This analysis (Table 1) included data from days 0,14 , and 28 , and covariate analysis was not used for this analysis because gender was predetermined such that the use of covariates would remove much of the effect of gender. In $m$. longissimus, protein synthesis rates tended to be greater in steers than in heifers $(P=0.10)$. Gender did not affect protein synthesis rates in m. biceps femoris $(P=0.76)$ or protein degradation rates in $m$. biceps femoris and $m$. longissimus $(P \geq 0.42)$.

Table 1 Effect of gender on protein turnover in finishing cattle

\begin{tabular}{|c|c|c|c|c|}
\hline Item & Heifers & Steers & S.E.M. ${ }^{*}$ & $P$-value \\
\hline $\mathrm{n}$ & 16 & 16 & & \\
\hline \multicolumn{5}{|c|}{ Protein synthesis $(\mu \mathrm{g}$ Tyr $/[\mathrm{g}$ wet tissue $\times \mathrm{h}])$} \\
\hline M. biceps femoris & 0.313 & 0.309 & 0.011 & 0.76 \\
\hline M. longissimus & 0.291 & 0.304 & 0.0093 & 0.10 \\
\hline \multicolumn{5}{|c|}{ Protein degradation $(\mu \mathrm{g} \mathrm{Tyr} /[\mathrm{g}$ protein $\times \mathrm{h}])$} \\
\hline M. biceps femoris & 92 & 86 & 6.0 & 0.42 \\
\hline M. longissimus & 68 & 66 & 4.0 & 0.64 \\
\hline
\end{tabular}

"Largest S.E.M. among treatments.

Effects of gender on RNA, DNA, and protein concentrations as well as ratios of these components are presented in Table 2. Gender did not affect RNA, DNA, and protein concentrations or protein : DNA, protein : RNA, and RNA : DNA ratios.

Table 2 Effects of ractopamine and gender on RNA, DNA, and protein concentrations in the $m$. biceps femoris and $m$. longissimus on day 28

\begin{tabular}{|c|c|c|c|c|c|c|c|c|}
\hline \multirow[b]{3}{*}{ Item } & \multicolumn{4}{|c|}{ Ractopamine, mg/d } & \multirow[b]{3}{*}{ S.E.M. ${ }^{*}$} & \multirow{2}{*}{\multicolumn{3}{|c|}{$P$-value }} \\
\hline & \multicolumn{2}{|c|}{0} & \multicolumn{2}{|c|}{200} & & & & \\
\hline & Heifers & Steers & Heifers & Steers & & $\mathrm{G}$ & $\mathrm{R}$ & $\mathrm{G} \times \mathrm{R}$ \\
\hline $\mathrm{n}$ & 8 & 8 & 8 & 8 & & & & \\
\hline \multicolumn{9}{|l|}{ M. biceps femoris } \\
\hline RNA (mg/g) & 0.199 & 0.206 & 0.200 & 0.209 & 0.017 & 0.62 & 0.90 & 0.94 \\
\hline DNA $(\mathrm{mg} / \mathrm{g})$ & 0.220 & 0.207 & 0.180 & 0.210 & 0.023 & 0.68 & 0.38 & 0.30 \\
\hline Protein (mg/g) & 103 & 102 & 103 & 101 & 4.2 & 0.65 & 0.91 & 0.85 \\
\hline Protein:DNA & 512 & 563 & 579 & 556 & 73 & 0.83 & 0.66 & 0.58 \\
\hline Protein:RNA & 535 & 531 & 529 & 513 & 46 & 0.82 & 0.77 & 0.88 \\
\hline RNA:DNA & 1.02 & 1.15 & 1.12 & 1.12 & 0.16 & 0.63 & 0.82 & 0.63 \\
\hline \multicolumn{9}{|l|}{ M. longissimus } \\
\hline RNA (mg/g) & 0.193 & 0.193 & 0.186 & 0.203 & 0.013 & 0.42 & 0.84 & 0.41 \\
\hline DNA (mg/g) & 0.161 & 0.171 & 0.161 & 0.166 & 0.025 & 0.74 & 0.90 & 0.92 \\
\hline Protein (mg/g) & 100 & 107 & 97 & 101 & 3.2 & 0.11 & 0.11 & 0.62 \\
\hline Protein:DNA & 686 & 860 & 698 & 634 & 128 & 0.65 & 0.38 & 0.33 \\
\hline Protein:RNA & 529 & 598 & 525 & 508 & 50 & 0.55 & 0.29 & 0.33 \\
\hline RNA:DNA & 1.33 & 1.44 & 1.37 & 1.30 & 0.23 & 0.91 & 0.74 & 0.60 \\
\hline
\end{tabular}

G - gender; R - ractopamine; * Largest S.E.M. among treatments. 
In vitro skeletal muscle protein synthesis and degradation rates across gender, ractopamine treatment, and sampling day are presented in Table 3. It should be noted that the effects of gender cannot be determined from the data in Table 3 because gender was predetermined and covariate analysis therefore removes much of the effect of gender; however, the interaction of gender with other treatments can still be reliably compared. Ractopamine did not affect protein synthesis rates in either muscle $(P \geq 0.53)$. Ractopamine decreased in vitro protein degradation rates in $m$. longissimus $(P=0.03)$ but did not influence them in $m$. biceps femoris $(P=0.19)$. Ractopamine did not demonstrate two-way interactions with either sampling day or gender $(P \geq 0.38)$ for protein synthesis or degradation in either muscle.

Table 3 Effect of ractopamine and gender on protein turnover in finishing steers and heifers fed 0 or 200 $\mathrm{mg} / \mathrm{d}$ of ractopamine for 14 or $28 \mathrm{~d}$

\begin{tabular}{|c|c|c|c|c|c|c|c|c|c|c|c|c|c|c|}
\hline \multirow[b]{4}{*}{ Item } & \multicolumn{8}{|c|}{ Ractopamine (mg/d) } & & & & & & \\
\hline & \multicolumn{4}{|c|}{0} & \multicolumn{4}{|c|}{200} & & & & & & \\
\hline & \multicolumn{2}{|c|}{ Heifers } & \multicolumn{2}{|c|}{ Steers } & \multicolumn{2}{|c|}{ Heifers } & \multicolumn{2}{|c|}{ Steers } & & \multicolumn{5}{|c|}{$P$-value } \\
\hline & $14 \mathrm{~d}$ & $28 \mathrm{~d}$ & $14 \mathrm{~d}$ & $28 \mathrm{~d}$ & $14 \mathrm{~d}$ & $28 \mathrm{~d}$ & $14 \mathrm{~d}$ & $28 \mathrm{~d}$ & S.E.M. ${ }^{*}$ & $\mathrm{R}$ & $\mathrm{R} \times \mathrm{D}$ & $\mathrm{G} \times \mathrm{D}$ & $\begin{array}{c}\mathrm{G} \times \\
\mathrm{R}\end{array}$ & $\begin{array}{c}\mathrm{G} \times \mathrm{R} \times \\
\mathrm{D}\end{array}$ \\
\hline$n$ & 8 & 8 & 8 & 8 & 8 & 8 & 8 & 8 & & & & & & \\
\hline \multicolumn{15}{|c|}{ Protein synthesis $(\mu \mathrm{g}$ Tyr $/[\mathrm{g}$ wet tissue $\times \mathrm{h}])$} \\
\hline$M b f$ & 0.319 & 0.276 & 0.333 & 0.270 & 0.329 & 0.291 & 0.323 & 0.287 & $7 \quad 0.017$ & 0.53 & 0.41 & 0.64 & 0.71 & 0.56 \\
\hline$M l$ & 0.312 & 0.257 & 0.318 & 0.286 & 0.304 & 0.263 & 0.328 & 0.259 & 0.014 & 0.58 & 0.38 & 0.88 & 0.70 & 0.07 \\
\hline \multicolumn{15}{|c|}{ Protein degradation $(\mu \mathrm{g}$ Tyr $/[\mathrm{g}$ protein $\times \mathrm{h}])$} \\
\hline$M b f$ & 87 & 92 & 81 & 74 & 110 & 107 & 85 & 80 & 12 & 0.19 & 0.75 & 0.56 & 0.42 & 0.66 \\
\hline$M l$ & 66 & 73 & 74 & 68 & 62 & 56 & 59 & 64 & 6.8 & 0.03 & 0.85 & 0.88 & 0.96 & 0.13 \\
\hline
\end{tabular}

The use of day-0 data in covariate analysis removed much of the effect of gender. The effects of gender should be evaluated using data presented in Table 1.

D - day; R - ractopamine; G - gender; Mbf - m. biceps femoris; $M l$ - m. longissimus.

${ }^{*}$ Largest S.E.M. among treatments.

In $m$. longissimus, the decrease in protein synthesis between days 14 and 28 tended to be greater for heifers than for steers when no ractopamine was fed but tended to be greater for steers than for heifers when $200 \mathrm{mg} / \mathrm{d}$ of ractopamine was fed (gender $\times$ ractopamine $\times$ day, $P=0.07$ ). Also in the $m$. longissimus, protein degradation demonstrated a trend $(P=0.13)$, with the gender $\times$ ractopamine $\times$ day interaction showing responses opposite those for protein synthesis. Heifers fed no ractopamine and steers fed $200 \mathrm{mg} / \mathrm{d}$ of ractopamine had increases in protein degradation between days 14 and 28, whereas steers fed no ractopamine and heifers fed $200 \mathrm{mg} / \mathrm{d}$ of ractopamine had decreases between days 14 and 28. Although the biological meaning of these interactions is unclear, the fact that protein degradation demonstrated movements opposite of those for protein synthesis might suggest these interactions were not randomly spawned.

Effects of ractopamine and its interaction with gender for RNA, DNA, and protein concentrations as well as ratios of these components are presented in Table 2. Ractopamine did not affect RNA, DNA, and protein concentrations or protein : DNA, protein : RNA, and RNA : DNA ratios.

\section{Discussion}

This study was conducted primarily to assess effects of ractopamine and determine if responses to ractopamine were similar for steers and heifers. In this trial, both steers and heifers received steroidal implants containing trenbolone acetate and estradiol, although in slightly different amounts (120 mg trenbolone acetate and $24 \mathrm{mg}$ estradiol for steers $v s .140 \mathrm{mg}$ trenbolone acetate and $14 \mathrm{mg}$ estradiol for heifers). Thus, the effects of gender in this study include effects of gender per se, of the minor differences in the steroid amounts in the implants, and of any differences between steers and heifers in how they responded 
to the implantation. Implants containing trenbolone acetate and estradiol increase growth performance of both genders, although implanted steers are still capable of greater growth rates than implanted heifers. It is possible that the effects of ractopamine would differ in non-implanted cattle. Nonetheless, cattle were implanted before their use in this experiment to simulate predominant practices of the cattle finishing industry of the United States.

Greater serum concentrations of insulin-like growth factor-I were observed in the steers than in the heifers (Walker et al., 2010), and this could be partially responsible for the observed tendency for greater rates of protein synthesis in the $m$. longissimus of steers than of heifers. Because steers generally gain body weight more rapidly and deposit more lean tissue than heifers, the observed difference in protein synthesis rate is not surprising.

Wheeler \& Koohmaraie (1992) demonstrated a 27\% decrease in fractional protein degradation rates of skeletal muscle myofibrillar protein and a numerical increase in fractional protein synthesis rates of skeletal muscle myofibrillar protein after three weeks in steers fed $3 \mathrm{mg} / \mathrm{kg}$ of the $\beta$-agonist $\mathrm{L}_{644,969}$. In the $m$. biceps femoris of lambs fed $4 \mathrm{mg} / \mathrm{kg}$ of $\mathrm{L}_{644,969}$ for six weeks, calpastatin activity was increased, whereas activities of $\mu$-calpain and m-calpain were not affected, suggesting that the calpastatin activity may be the key effecter of decreased protein degradation (Koohmaraie et al., 1991). Using a protocol with continuous infusion of label, Bergen et al. (1989) reported that fractional protein synthesis and degradation rates in the $m$. semitendinosus were $4.4 \% / \mathrm{d}$ and $3.4 \% / \mathrm{d}$ for control pigs and $6.1 \% / \mathrm{d}$ and $4.9 \% / \mathrm{d}$ for pigs fed $20 \mathrm{mg} / \mathrm{kg}$ ractopamine for 21 or $35 \mathrm{~d}$, demonstrating increases in rates of both protein synthesis and degradation in response to ractopamine. Using flooding dose methodology, Nash et al. (1994) observed that the $\beta$-agonist cimaterol led to increases in both protein synthesis and degradation rates in m. longissimus of sheep. Clearly, the use of different animal models, different $\beta$-agonists, and different research methodologies has contributed to divergent conclusions.

In this study, ractopamine decreased rates of protein degradation in the m. longissimus, which supports data reported by Wheeler \& Koohmaraie (1992). In contrast to the effect of ractopamine on protein degradation in the $m$. longissimus, ractopamine did not affect protein degradation rates in the $m$. biceps femoris; differences between muscles in response to ractopamine feeding may be attributable to differences in fibre type. Gonzalez et al. (2009) evaluated the impact of feeding $200 \mathrm{mg} / \mathrm{d}$ of ractopamine to finishing steers on the muscle fibre type in six muscles. In four of the six muscles studied (including m. longissimus), ractopamine decreased the percentage of type I fibres and increased the percentage of type II fibres. In contrast, ractopamine did not affect the percentage of fibre types in m. semimembranosus, and it increased type I fibres and decreased type II fibres in m. rectus femoris. Similarly, Gonzalez et al. (2008) demonstrated differences among muscles in cull cows in response to ractopamine in terms of changes in fibre type. Thus, ractopamine can convert slow-twitch fibres to fast-twitch fibres as demonstrated by changes in fibre type and the prevalence of different isoforms of myosin heavy chains. In these cattle, mRNA expression of myosin heavy-chain IIA was reduced in $m$. biceps femoris but not $m$. longissimus (Walker et al., 2010), which suggests that ractopamine led to greater changes in fibre type in $m$. biceps femoris than in $m$. longissimus. This could account for the different effects of ractopamine on protein degradation in $m$. longissimus and m. biceps femoris.

In this study, ractopamine did not affect calpastatin mRNA expression in $m$. biceps femoris, but it numerically $(P=0.17)$ increased calpastatin mRNA expression by $20 \%$ in $m$. longissimus (Walker et al., 2010). Although calpastatin activity may not perfectly match mRNA expression for calpastatin, the observed changes in calpastatin mRNA matched the expected response in protein degradation in both muscles. Calpastatin regulates the activity of m-calpain and $\mu$-calpain, which are responsible for initiating myofibrillar protein disassembly and, therefore, changes in mRNA expression of calpastatin could reflect regulatory mechanisms that could have led to the observed changes in protein degradation in $m$. longissimus.

Although the in vitro rates of protein synthesis and degradation are not reflective of in vivo rates because of the nature of the sample and assay, the goal was to assess changes due to ractopamine. Samples were collected with a Bergstrom biopsy needle that produced small tissue pieces, which could limit the ability to measure true protein synthesis and degradation rates. Additionally, the in vitro protein synthesis and degradation assays did not differentiate the myofibrillar protein fraction from total protein. Therefore, it is possible that differences may not reflect changes in myofibrillar protein turnover.

Changes in protein, DNA or RNA concentrations were not observed in either muscle. More aggressive treatments with $\beta$-agonists have increased protein : DNA and RNA : DNA ratios in muscle of 
lambs. O'Connor et al. (1991) demonstrated $42 \%$ and 25\% reductions in DNA concentrations, $25 \%$ and $12 \%$ increases in RNA concentrations, and $1 \%$ and $13 \%$ increases in protein concentrations in the semitendinosus of ram lambs fed $10 \mathrm{mg} / \mathrm{kg}$ cimaterol for three and six weeks, respectively. Also in that study, the protein : DNA ratio increased by $76 \%$ and $51 \%$, the protein : RNA ratio decreased by $21 \%$ and $2 \%$, and the RNA : DNA ratio increased by $109 \%$ and $52 \%$. Beermann et al. (1987) demonstrated a $22 \%$ decrease in DNA concentration in semitendinosus in lambs fed $10 \mathrm{mg} / \mathrm{kg}$ of cimaterol for seven weeks, and RNA and protein concentrations in semitendinosus were increased by $9 \%$ and $8.1 \%$, respectively, when lambs were fed cimaterol for 12 weeks. In addition, the protein : DNA ratio increased by $22 \%$ and $8 \%$, the protein : RNA ratio decreased by $5 \%$ and $1 \%$, and the RNA : DNA ratio increased by $29 \%$ and $10 \%$ after seven and 12 weeks, respectively, of cimaterol feeding. These changes show that $\beta$-agonists increase hypertrophic growth (protein) with little impact on proliferation of satellite cells or their incorporation in muscle fibres (O'Connor et al., 1991). No differences in muscle composition were observed among treatments in the present study, which may reflect no true difference or, more likely, the relatively modest effects of $200 \mathrm{mg} / \mathrm{d}$ of ractopamine fed to finishing cattle for $28 \mathrm{~d}$, which might have led to an inability to detect differences.

\section{Conclusions}

The results indicate that ractopamine fed to steers and heifers implanted with trenbolone acetate and estradiol affects in vitro protein degradation rates of $m$. longissimus and $m$. biceps femoris differently. There were no striking disparities to suggest the impact of ractopamine on protein turnover differs markedly between genders.

\section{Acknowledgements} $\mathrm{KS}$, USA.

This paper is contribution no. 10-143-J from the Kansas Agricultural Experiment Station, Manhattan,

\section{References}

Avendano-Reyes, L., Torres-Rodriguez, V., Meraz-Murillo, F.J., Perez-Linares, C., Figueroa-Saavedra, F. \& Robinson, P.H., 2006. Effects of two $\beta$-adrenergic agonists on finishing performance, carcass characteristics, and meat quality of feedlot steers. J. Anim. Sci. 84, 3259-3265.

Beermann, D.H., Butler, W.R., Hogue, D.E., Fishell, V.K., Dalrymple, R.H., Ricks, C.A. \& Scanes, C.G., 1987. Cimaterol-induced muscle hypertrophy and altered endocrine status in lambs. J. Anim. Sci. 65, 1514-1524.

Bergen, W.G., Johnson, S.E., Skjaerlund, D.M., Babiker, A.S., Ames, N.K., Merkel, R.A. \& Anderson, D.B., 1989. Muscle protein metabolism in finishing pigs fed ractopamine. J. Anim. Sci. 67, 2255-2262.

Blin, N. \& Stafford, D.W., 1976. A general method for isolation of high molecular weight DNA from eukaryotes. Nucleic Acid Res. 3, 2303-2308.

Dunn, J.D., Johnson, B.J., Kayser, J.P., Waylan, A.T., Sissom, E.K. \& Drouillard, J.S., 2003. Effects of flax supplementation and a combined trenbolone acetate and estradiol implant on circulating insulin-like growth factor-I and muscle insulin-like growth factor-I messenger RNA levels in beef cattle. J. Anim. Sci. 81, 3028-3034.

Gonzalez, J.M., Dijkhuis, R.D., Johnson, D.D., Carter, J.N. \& Johnson, S.E., 2008. Differential response of cull cow muscles to the hypertrophic actions of ractopamine-hydrogen chloride. J. Anim. Sci. 86, 3568-3574.

Gonzalez, J.M., Johnson, S.E., Thrift, T.A., Savell, J.D., Ouellette, S.E. \& Johnson, D.D., 2009. Effect of ractopamine-hydrochloride on the fiber type distribution and shelf-life of six muscles of steers. J. Anim. Sci. 87, 1764-1771.

Greig, P.D., Rozovski, S.J., Elwyn, D.H. \& Kinney, J.M., 1986. Protein synthesis and degradation in biopsies of rat skeletal muscle. J. Surg. Res. 40, 248-260.

Gruber, S.L., Tatum, J.D., Engle, T.E., Mitchell, M.A., Laudert, S.B., Schroeder, A.L. \& Platter, W.J., 2007. Effects of ractopamine supplementation on growth performance and carcass characteristics of feedlot steers differing in biological type. J. Anim. Sci. 85, 1809-1815.

Koohmaraie, M., Shackelford, S.D., Muggli-Cockett, N.E. \& Stone, R.T., 1991. Effect of the $\beta$-adrenergic 
agonist $\mathrm{L}_{644,969}$ on muscle growth, endogenous proteinase activities, and postmortem proteolysis in wether lambs. J. Anim. Sci. 69, 4823-4835.

Labarca, C. \& Paigen, K., 1980. A simple, rapid, and sensitive DNA assay procedure. Anal. Biochem. 102, 344-352.

Mersmann, H.J., 1998. Overview of the effects of $\beta$-adrenergic receptors on animal growth including mechanism of action. J. Anim. Sci. 76, 160-172.

Moody, D.E., Hancock, D.L. \& Anderson, D.B., 2000. Phenethanolamine repartitioning agents. In: Farm Animal Metabolism and Nutrition. Ed. D’Mello, J.P.F., CAB International, Wallingford, Oxon, UK. pp. 65-96.

Nash, J.E., Rocha, H.J.G., Buchanz, V., Calder, G.A., Milne, E., Quirke, J.F. \& Lobley, G.E., 1994. The effect of acute and chronic administration of the $\beta$-agonist, cimaterol, on protein synthesis in ovine skin and muscle. Br. J. Nutr. 71, 501-513.

O'Connor, R.M., Butler, W.R., Hogue, D.E. \& Beermann, D.H., 1991. Temporal pattern of skeletal muscle changes in lambs fed cimaterol. Domestic Anim. Endocrinol. 8, 549-554.

Pampusch, M.S., Johnson, B.J., White, M.E., Hathaway, M.R., Dunn, J.D., Waylan, A.T. \& Dayton, W.R., 2003. Time course of changes in growth factor mRNA levels in muscle of steroid-implanted and nonimplanted steers. J. Anim. Sci. 81, 2733-2740.

Quinn, M.J., Reinhardt, C.D., Loe, E.R., Depenbusch, B.E., Corrigan, M.E., May, M.L. \& Drouillard, J.S., 2008. The effects of ractopamine-hydrogen chloride (Optaflexx) on performance, carcass characteristics, and meat quality of finishing feedlot heifers. J. Anim. Sci. 86, 902-908.

Sissom, E.K., Reinhardt, C.D., Hutcheson, J.P., Nichols, W.T., Yates, D.A., Swingle, R.S. \& Johnson, B.J., 2007. Response to ractopamine- $\mathrm{HCl}$ in heifers is altered by implant strategy across days on feed. J. Anim. Sci. 85, 2125-2132.

Waalkes, T.P. \& Udenfriend, S.A., 1957. A fluorometric method for the estimation of tyrosine in plasma and tissues. J. Lab. Clin. Med. 50, 733-736.

Walker, D.K., Titgemeyer, E.C., Baxa, T.J., Chung, K.Y., Johnson, D.E., Laudert, S.B. \& Johnson, B.J., 2010. Effects of ractopamine and sex on serum metabolites and skeletal muscle gene expression in finishing steers and heifers. J. Anim. Sci. 88, 1349-1357.

Wheeler, T.L. \& Koohmaraie, M., 1992. Effects of $\beta$-adrenergic agonist $\mathrm{L}_{644,969}$ on muscle protein turnover, endogenous proteinase activities, and meat tenderness in steers. J. Anim. Sci. 70, 3035-3043.

Winterholler, S.J., Parsons, G.L., Reinhardt, C.D., Hutcheson, J.P., Nichols, W.T., Yates, D.A., Swingle, R.S. \& Johnson, B.J., 2007. Response to ractopamine-hydrogen chloride is similar in yearling steers across days on feed. J. Anim. Sci. 85, 413-419. 